\title{
ISB News January 2011: From the President
}

\author{
Paul J. Beggs
}

(C) ISB 2010

This year, 2011, will be a particularly eventful year for the International Society of Biometeorology. The Society's triennial conference, the International Congress of Biometeorology, will be the climax of our year, scheduled for 5-9 December 2011. Prof Glenn McGregor (the Congress Chair) and I have compiled a list of some of the exciting developments in the organisation of the Congress below. 2011 is also an important year for the Society because an election for the Society's Executive Board will take place, with the change from the current Board to the next to occur at the Congress in December. Members of the Society will hear more about the election in the coming months, but I encourage all to both consider standing for a position on the Board, and of course to vote when the time comes. Another thing to look forward to, especially for the Society's younger members, will be the Tromp Award. Again, details of this will be communicated soon, including through a new page dedicated to this on the Society's web site (www. biometeorology.org).

The Congress (ICB2011) will be held in Auckland, New Zealand. The venue is now confirmed as The University of Auckland Business School's Owen G. Glenn Building. This is an outstanding facility, pictures of which can be found on the ICB2011 web site (http://www.icb2011.com/).

We are delighted to announce publically for the first time that a keynote address will be delivered by Dr. Michael $\mathrm{H}$.
Glantz, Director of the Consortium for Capacity Building (CCB), located within the Environmental Studies Program (ENVS) and Institute of Arctic and Alpine Research (INSTAAR), University of Colorado at Boulder. As is stated on Dr Glantz's Home Page (http://ccb.colorado.edu/glantz), "He is interested in how climate affects society and how society affects climate, especially in how the interaction between climate anomalies and human activities affect quality of life issues". Dr Glantz's address will no doubt be inspirational, especially given the theme of the Congress: Climate and Society. Other keynote speakers will be announced soon.

The Congress is also attracting sponsorship from a range of sources. Recently, sponsorship has been provided by the Australian National Climate Change Adaptation Research Facility (NCCARF), through its National Climate Change Adaptation Research Network for Human Health (http://www.nccarf.edu.au/humanhealth/).

The Congress will offer members of ISB a discounted registration rate. To learn more about becoming a member please visit the ISB web site shown above. We look forward to welcoming both members and nonmembers of the Society to the 19th International Congress of Biometeorology in Auckland in December, for what is shaping up to be a fascinating and enjoyable conference.
P. J. Beggs $(\bowtie)$

Environmental Science, Department of Environment

and Geography, Macquarie University,

Sydney, Australia

e-mail: paul.beggs@mq.edu.au 